\title{
Maize Breeding in the Highlands of Ecuador, Peru, and Bolivia: A Review
}

\author{
José Luis Zambrano ${ }^{1, * \mathbb{D}}$, Carlos F. Yánez ${ }^{1}$ and Carlos A. Sangoquiza ${ }^{2}$ \\ 1 INIAP, Estación Experimental Santa Catalina, Panamericana sur Km 1, Cutuglahua 171108, Ecuador; \\ cayanez@hotmail.com \\ 2 KOPIA, Panamericana sur Km 1-dentro de la Estación Experimental Santa Catalina, \\ Cutuglahua 171108, Ecuador; ci2801@hotmail.com \\ * Correspondence: jose.zambrano@iniap.gob.ec; Tel.: +593-2-307-6004
}

check for

updates

Citation: Zambrano, J.L.; Yánez, C.F.; Sangoquiza, C.A. Maize Breeding in the Highlands of Ecuador, Peru, and Bolivia: A Review. Agronomy 2021, 11, 212. https://doi.org/10.3390/ agronomy11020212

Academic Editor: Bernardo Ordas Received: 15 December 2020

Accepted: 14 January 2021

Published: 23 January 2021

Publisher's Note: MDPI stays neutral with regard to jurisdictional claims in published maps and institutional affiliations.

Copyright: (c) 2021 by the authors. Licensee MDPI, Basel, Switzerland. This article is an open access article distributed under the terms and conditions of the Creative Commons Attribution (CC BY) license (https:// creativecommons.org/licenses/by/ $4.0 /)$.

\begin{abstract}
Maize is one of the most important staple crops in the highlands of the Andean region of Ecuador, Peru, and Bolivia. Most seeds come from landraces, with their own kernel characteristics. The kernels are used for the elaboration of traditional dishes and other elaborates for human consumption. In this region, maize breeding is conducted mainly by public institutions. In this review, we outline the methodology that has been used by the maize breeding programs (MBPs) of the National Institutes for Agricultural Research and other institutions in the highlands of Ecuador, Peru, and Bolivia during the last 20 years. The main objective of MBPs in the region has been to develop more uniform and productive open-pollinated varieties (OPVs) of floury maize (Zea mays L. var. Amylacea), which is the most important type of maize in the area. Participatory plant breeding, combined with half-sib, has been used to breed new maize varieties. At least 18 OPVs of floury maize have been released into the Andean region in the last 20 years. Breeding this type of maize has been very important to conserve diversity and promote consumption in the region, but they have had very little impact on yield. The yield of floury maize is around three times below that of dent or semident maize grown in the region. Therefore, there is a need to apply new breeding techniques in the region to accelerate the development of more productive floury-maize cultivars.
\end{abstract}

Keywords: floury maize; yield; seed

\section{Introduction}

In the highlands of Ecuador, Peru, and Bolivia, between 1700 and $3500 \mathrm{~m}$ above sea level (masl), there are numerous densely inhabited valleys where the cultivation of floury maize (Zea mays L. var. Amylacea) is one of the main sources of calories in the diet of the rural population since almost all production is dedicated to human consumption [1-3]. Most of the farmers of these regions are poor owners of small farms (less than $0.5 \mathrm{ha}$ ) with very steep slopes and eroded soils [4]. In addition, in southern Peru and Bolivia, maize is commonly affected by drought and cold that occur in areas above 3000 masl [1,5,6], and hail and frost prematurely can end or reduce maize production [7].

Floury corn is mainly intended for human consumption in the form of fresh corn (choclo), dry toasted kernels (tostado, cancha), soups (chuchuca), drinks (chicha, colada, maicena), breads, and other traditional preparations [8]. Additionally, the cane and leaves are used as fodder for guinea pigs, sheep, and cattle. The dry grain is also used to prepare a concentrate for raising poultry, pigs, and guinea pigs. The grain is a source of energy and amino acids due to its starch, protein, and oil content. It also contains nine minerals $(\mathrm{K}, \mathrm{Fe}$, $\mathrm{Zn}, \mathrm{Ca}, \mathrm{P}, \mathrm{Si}, \mathrm{Cu}$ and $\mathrm{Mg}$ ), nine vitamins (B4, B6, C, E, B2, B3, B1, B9, and A), and phenolic compounds and anthocyanin, in the case of black, red, and blue corn $[9,10]$.

In Ecuador, Peru, and Bolivia, floury maize is grown only in the highlands at around $418,000 \mathrm{ha}$, which corresponds to approximately $30 \%$ of the average maize production of those countries [11-13]. In Ecuador, the area harvested with floury maize was 67,620 ha 
in 2019, with a yield of 1.36 tha $^{-1}$ [11]. In the north of this country (provinces of Carchi, Imbabura, Pichincha, and Cotopaxi), traditional races called chauchos, huandangos, and mishcas are generally sown (soft yellow kernels). In the central zone (provinces of Chimborazo, Tungurahua, and Bolívar), floury white races of maize are preferably cultivated, such as blanco blandito, chazo, and guagal. In the south (provinces of Cañar and Azuay), the type of maize called zhima (white semident kernel) belonging to the cusco ecuatoriano race, is mostly grown [14].

Maize is the most important short-term crop in Peru. Around 280,000 ha are cultivated in the High Andean region, the vast majority corresponding to floury maize [12]. Although floury maize is grown throughout the highlands, the regions with the highest production are Cusco, Apurimac, Cajamarca, Ayacucho, and Huancavelica [15]. The national average floury maize yield is 1.29 tha $^{-1}$, with a maximum yield in the region of Cusco of 2.23 tha $^{-1}$ and the lowest yield in Cajamarca with 0.78 tha $^{-1}$ [16].

Floury maize is one of the most important crops for the Bolivian food and economy. It is estimated that, in the Andean valleys of Bolivia (regions of La Paz, Cochabamba, Oruro, and Potosí), around 115,000 ha are sown, which represents around $20 \%$ of the area sown with maize in the country. The average floury maize yield in Bolivia is 1.2 tha $^{-1}$ [13]. In the high valleys, there is a large number of traditional varieties due to the diverse uses for human consumption. The most important native varieties in this region are karapampa, kellu, uchupilla, hualtaco, huillcaparu, pasakalla, chuspillo checchi, and kulli chunkula [17].

Formal maize breeding in the Andean region began in the 1960s, with the establishment of the Public Research Institutes (INIA). In the 1980s, the International Maize and Wheat Improvement Center (CIMMYT), located in Quito (2850 masl), generated eight Andean pools that were populations with a broad genetic base: Pool 1 (early floury white), Pool 2 (late floury white), Pool 3 (early floury yellow), Pool 4 (late floury yellow), Pool 5 (early dent white), Pool 6 (early dent yellow), Pool 7 (late dent white) and Pool 8 (late dent/flint yellow), which subsequently resulted in the release of several open-pollinated varieties (OPVs). Breeding was based mainly on recombination (diallelic crosses), mass selection (SM), half-sib, performance tests, regional adaptation trials, and Andean regional trials [1].

This review describes the main methods used by the maize breeding programs (MBP) to conserve and improve native Andean races in the last 20 years, preserving the tradition and nutritional value of floury corn. It also describes the varieties released in this period and analyzes the future of the genetic improvement of this type of maize. This information is useful to plant breeders in the Andean region and other parts of the world, where social aspects of farmers and breeding strategies used by the MBP are similar.

\section{Genetic Diversity of Maize in the Region}

The geographical, environmental, and social characteristics of the highlands of Ecuador, Peru, and Bolivia created conditions for the development of many races of maize. These traditional races, which have had various names such as creole breeds, farmer varieties, landraces, or local varieties, have been improved by farmers for a long time, and most of them have not been subjected to selection and improvement methods by breeders (Figure S1).

In Latin America, 252 races of maize were described, 132 of which are from the Andean region [18-20]. In Ecuador, 29 races of maize were described, and 17 were found in the highlands, 6 of which are not well defined [14]. In Peru, there are 52 races of maize, and 32 are grown in the highlands; 40 races were described in Bolivia, and 31 are cultivated in the highlands [21].

Andean maize has great variability in grain color, texture, composition, and appearance, and represents an invaluable source of genes for resistance to abiotic stress that is not yet exploited [22]. Maize landraces are a good source to convert native varieties into improved varieties without affecting crop diversity because they have already adapted to 
the particular conditions of the region, they have the characteristics of commercial value, and the population already knows them and has a habit of consuming them [23].

\section{Breeding Methods Used in the Region}

Maize breeding has been very important in the Andean countries to conserve diversity and promote consumption, especially in Bolivia, Ecuador, and Peru, but they have had very little impact on yield (at the national level). One of the reasons for this is that selection has been oriented toward maintaining grain quality for human consumption (texture and color) and introducing foreign germplasms to improve the nutritional quality of the grain (QPM) and disease resistance [24,25]. Another reason is the lack of a certified seed system that distributes seeds of improved OPVs to farmers [26,27].

In general, Andean germplasm is adapted to specific environments; each time this germplasm was crossed with a foreign variety, it lost some of its characteristics, and recovery with backcrosses took many generations to fully recuperate the Andean phenotype, which is absolutely necessary to achieve adoption of the varieties [28].

The development, formation, and maintenance of OPV has been very similar in the three Andean countries due to CIMMYT's influence in training scientists in the region. The most frequently used selection methods in the region are half-sib and MS [29]. Briefly, the breeding process begins by identifying between 8 to 10 of the best accessions or families on the basis of their behavior in trials in several locations and performing diallelic crosses to form the initial OPV (Cycle 0). The F1 seed must be advanced to F2 by manual pollination. Then, 100 to 200 manually fertilized ears are selected, and an equal number of seeds from each ear is mixed to produce the F2 seed. Then, ear families are evaluated and selected on a recurring basis through half-siblings, and after 4 to 6 cycles, evaluations are carried out in experiment stations and in the farmers' fields. Validation tests are carried out before the official release of the new variety [30].

The genetic gain of the OPV obtained by MS and half-sib was evaluated in Peru and Ecuador. In Peru, seven populations were improved by MS and eight through half-sibs. The selection gain for yield using MS, estimated by linear regression, was 3.5\% per cycle (year) on average; for the half-sib method, it was 4.6\% [31]. In Ecuador, the genetic gain for yield in two Andean pools using half-sib was $1.4 \%$ per cycle (year) on average [32]. These pools are the origin of two OPVs sown in the highlands of Ecuador for more than 30 years, with resistance to Exherohilum turcicum, Cercospora maydis, Puccinia spp., Fusarium moniliforme, and Maize rayado fino virus [33-35].

The use of a racial compound (RC) as an alternative population-breeding method was proposed in Peru. This method consists of the development of a cluster of all the native varieties of a race in a region, and letting them naturally recombine before MS. The RC tends to produce more than the average of the varieties that form it since it has more useful variability of adaptive characters, and it could be easily accessible to farmers [36].

The development of hybrids using floury maize germplasm has not prospered in the region. This is due to the high degree of inbreeding that is generated during self-pollination, causing the degeneration and the null formation of grains in the ears. However, trials carried out in Peru showed that it is possible to generate parental lines from populations that were improved by a recurrent selection method [37].

\section{Breeding for Resistance to Ear Root}

Ear rot caused by Fusarium moniliforme and other species is one of the main limitations for the production of floury corn in the region, reaching losses of up to $40 \%$ of the yield [12,27]. The work on the regional level to incorporate genetic resistance to diseases in the highlands began with the Durable Resistance Project for the Andean Zone (PREDUZA) in 1998. The five-year project was based on crossing locally adapted cultivars with resistant genotypes, followed by participatory selection with farmers [38].

With PREDUZA, 41 trials were carried out in Ecuador, Bolivia, and Peru aiming to reduce the incidence of ear rot. The project was oriented toward identifying the components 
of durable resistance; for this purpose, in the first two years of the project, work was carried out on methods, times, and concentrations of inoculation with Fusarium verticillioides. Simultaneously with these works, genetic improvement activities were carried out in order to obtain varieties with good resistance levels, which were exchanged for evaluation among the countries. Likewise, in each country, extension work began, including field days, guided visits, and participatory research events [39]. These works allowed for the identification of Bolivian maize varieties Aychazara 102 and ODA with high levels of resistance to ear rot, reducing the severity of this disease by 55\% in Ecuador [40]. Aychazara 102 was later released in the highlands of Ecuador as INIAP 103 [41].

In the highlands of Peru, work continued to incorporate genetic resistance to ear rot in native floury maize through crosses between Peruvian Complex IV (resistant) and INIA-607 (susceptible), and after six generations, resistance to ear root was increased by $16 \%$ [12].

\section{Open Pollinated Maize Varieties Generated in the Andean Region}

\subsection{Ecuador}

Since 1961, the MBP of the National Institute for Agricultural Research (INIAP), based at the Santa Catalina Experiment Station, has dedicated its efforts to the improvement of native varieties. Since then, the objective of the MBP has been to develop OPVs that satisfy the needs and production systems of farmers in the highlands, on the basis of the local genetic diversity of maize. During the selection process, farmers have actively participated in agronomic evaluations. The selection method used by the MBP was half-sib, following CIMMYT procedures [30]. Since 2000, the MBP has released varieties INIAP-102 Blanco Blandito Mejorado, INIAP-124 Mischa Mejorado, INIAP-103 Misqui Sara, and INIAP-199 Racimo de uva (Table 1).

\subsection{Peru}

The development of maize OPVs began with the Collaborative Program for Maize Research (PCIM), founded in 1953 and based at the La Molina University, with partial funding from the Ministry of Agriculture of Peru. From the beginning, the program was oriented toward genetic improvement for the conservation of the racial diversity of maize, ex situ and in situ. Many local varieties were improved, with selection gains between 5 and $10 \%$ per cycle [23].

Later, the MBP of the National Institute of Agrarian Innovation (INIA), founded in 1978, used PCIM germplasm to form the following Peruvian complexes (CP): CP I: Choclero Precoz, CP II: Late Choclero; CP III: Canchero Precoz, CP IV: Canchero Tardío, CP V: Morocho Precoz, and CP VI: Morocho Tardío. At least 28 improved varieties emerged from these genetic pools [15]. In the last 20 years, INIA has released nine floury OPVs on the basis of the selection of native races, mainly through the use of the half-sib breeding method (Table 1).

\subsection{Bolivia}

There are several institutions in charge of the development of maize varieties in Bolivia, including the Pairumani Phytoecogenetic Research Center (CIFP), the National Institute for Agricultural and Forestry Innovation (INIAF), the International Center for Tropical Agriculture (CIAT), and the Institute for Agricultural Research El Vallecito (IIAEV). Additionally, all these institutions have strong involvement in the management and conservation of plant genetic resources. The institutions have given greater importance to the use of the local germplasm for their breeding programs. Between 10 and $60 \%$ of native germplasms were used by the MBP. The second source of use has been introductions of improved germplasms through bilateral or multilateral agreements. Crossing exotic and native maize germplasms, followed by MS, is the main breeding method used by the MBP in Bolivia [42]. 
Table 1. Floury open pollinated maize varieties generated in Ecuador, Peru and Bolivia in the last 20 years.

\begin{tabular}{|c|c|c|c|c|c|c|}
\hline Country & $\begin{array}{c}\text { Year of } \\
\text { Release or } \\
\text { Registration }\end{array}$ & Name & Color * & $\begin{array}{l}\text { Breeding } \\
\text { Method }\end{array}$ & $\begin{array}{c}\text { Range of } \\
\text { Altitude (masl) }\end{array}$ & Reference \\
\hline \multirow[t]{4}{*}{ Ecuador } & 2000 & $\begin{array}{c}\text { INIAP-102 } \\
\text { "Blanco blandito } \\
\text { mejorado" }\end{array}$ & White & Half-Sib & $2200-2800$ & [43] \\
\hline & 2002 & $\begin{array}{c}\text { INIAP-124 } \\
\text { "Mishca mejorado" }\end{array}$ & Yellow & Half-Sib & $2200-2900$ & [44] \\
\hline & 2013 & $\begin{array}{l}\text { INIAP-103 } \\
\text { "Mishqui Sara" }\end{array}$ & White & Half-Sib & $1700-2650$ & [41] \\
\hline & 2017 & $\begin{array}{c}\text { INIAP-199 } \\
\text { "Racimo de Uva" }\end{array}$ & Black & Half-Sib & 2400-3000 & [45] \\
\hline \multirow[t]{9}{*}{ Perú } & 2004 & $\begin{array}{l}\text { INIA } 603 \\
\text { Choclero }\end{array}$ & White & $\begin{array}{l}\text { Half-Sib } \\
\text { Full-Sib }\end{array}$ & 2600-3000 & [46] \\
\hline & 2004 & $\begin{array}{c}\text { INIA } 606 \\
\text { Choclero Prolífico }\end{array}$ & White & Half-Sib & 2200-2900 & [47] \\
\hline & 2005 & $\begin{array}{c}\text { INIA } 607 \\
\text { Ch'ecche Andenes }\end{array}$ & $\begin{array}{l}\text { Mottled gray } \\
\text { and purple }\end{array}$ & Half-Sib & $2900-3500$ & [48] \\
\hline & 2007 & $\begin{array}{c}\text { INIA } 615 \\
\text { Negro Canaán }\end{array}$ & Black & Half-Sib & 2000-3000 & [49] \\
\hline & 2012 & $\begin{array}{c}\text { INIA } 618 \\
\text { Blanco Quispicanchi }\end{array}$ & White & Half-Sib & $3100-3350$ & {$[50]$} \\
\hline & 2013 & $\begin{array}{c}\text { INIA } 620 \\
\text { Wari }\end{array}$ & White & Half-Sib & $2800-3400$ & [51] \\
\hline & 2013 & $\begin{array}{l}\text { INIA } 621 \\
\text { Pillpe }\end{array}$ & $\begin{array}{l}\text { Mottled gray } \\
\text { and white }\end{array}$ & Half-Sib & $2800-3400$ & [52] \\
\hline & 2014 & $\begin{array}{c}\text { INIA } 601 \\
\text { Maíz Morado }\end{array}$ & Black & Half-Sib & $2600-2900$ & [53] \\
\hline & 2020 & $\begin{array}{c}\text { INIA } 623 \\
\text { Cumbemaino }\end{array}$ & Yellow & Half-Sib & $2500-3000$ & {$[54]$} \\
\hline \multirow[t]{5}{*}{ Bolivia } & 2009 & Pairumani Choclero 2 & White & Mass Selection & $2000-2800$ & {$[55,56]$} \\
\hline & 2009 & Pairumani Choclero 3 & White & Mass Selection & $1800-2600$ & {$[56,57]$} \\
\hline & & Aychasara 102 & White & Mass Selection & $1800-2800$ & {$[24,58]$} \\
\hline & & Aychasara 7 & Black & Mass Selection & $2600-2800$ & {$[24,58]$} \\
\hline & 2019 & Morado Criollo & Black & Mass Selection & $2600-2800$ & {$[58]$} \\
\hline
\end{tabular}

* Figure S2.

CIFP has produced the largest number of varieties of floury maize in the highlands of Bolivia, generating varieties with kernels that look the same as those of native or traditional varieties, but with better nutritional quality (QPM), higher adaptability to various environments, and better performance. The opaque-2 gene donor was developed by CIMMYT (Tuxpeño Opaque-2). The crosses were followed by several cycles of MS [24]. Although several institutions are breeding maize in Bolivia, there is little available information about floury maize varieties. CIFP released four floury maize OPV in the last 20 years: Aychazara 7, Aychazara 102, Pairumani Choclero 2, and Pairumani Cholcero 3 (Table 1).

The MBP of INIAF has bred using native and improved maize germplasms, with the aim of improving quantitative and qualitative characteristics but maintaining local characteristics, such as earliness, disease tolerance, and organoleptic quality [28].

\section{Breeding Prospective}

Despite the fact that several institutions have been working with floury maize in the last 20 years, there is still little recognition of the role of native maize in the daily diet of people. It is necessary to increase research and disseminate the nutritional quality of native corn, such as black maize due to its high anthocyanin content, and to incorporate other nutritional characteristics such as $\mathrm{Zn}$ and pro vitamin $\mathrm{A}$ content in the grain. 
Modern tools such as double haploids, genomic selection, and gene editing must be incorporated into the $\mathrm{MBP}$ of the region in order to increase yield and resistance to diseases. The yield of floury maize in the region is similar to the yield that existed a hundred years ago in the United States, when OPVs were used [59]. Of course, the increase in yield must come with the improvement of agronomic practices since agronomy and genetics contribute in equal parts to the production of grain, although yield potential is driven by genetics [60].

Seed dissemination of the new varieties is a bottleneck for all plant breeding institutions in the Andean region of Ecuador, Peru, and Bolivia. These institutions make great efforts through communication networks and field days to have their improved OPVs reach farmers and consumers, but with disappointing results. This is reflected in the small area with improved varieties planted by farmers. The development of high-yield maize cultivars facilitates the development of seed companies, such as what happened in the lowlands of Ecuador, Peru, and Bolivia with the release of hybrids.

\section{Conclusions}

At least 18 OPVs of floury maize have been released in the highlands of Ecuador, Peru, and Bolivia in the last 20 years. These varieties were developed mainly using the half-sib breeding method in order to conserve native genetic diversity and grain quality (texture, color). Additionally, crossing between exotic and native germplasms was performed to incorporate the opaque-2 gen and resistance to ear rot, which is the main disease that affects this kind of maize.

Despite the achievements shown in terms of the number of released varieties, Andean maize in these three countries faces serious challenges: (a) breeding has not been able to significantly increase the yield of floury maize in the region, (b) floury maize is very susceptible to ear rot, and (c) there is no formal certified seed system that distributes improved seeds to farmers on a large scale.

In the future, it is necessary to implement in the MBP new biotechnological tools available for maize breeding in developed countries, such as double haploids and genomic editing. Additionally, it is crucial to implement a seed production and commercialization system between public and private institutions to promote the use of certified seeds. These innovations contribute to solving the above-mentioned challenges and reducing the time to obtain a new variety. This allows for the development of more productive and resistant maize cultivars.

Supplementary Materials: The following are available online at https:/ /www.mdpi.com/2073-439 5/11/2/212/s1, Figure S1: Samples of maize landraces found in the highlands of Ecuador, Peru, and Bolivia. It is shown the diversity of shapes, colors, and textures of ears and kernels which represents a great genetic diversity of maize found in the region. Figure S2: Ears of floury open pollinated maize varieties developed in the highlands of Ecuador, Peru, and Bolivia. Colors white, yellow, black, and mottled are shown.

Author Contributions: Conceptualization, J.L.Z.; methodology and search of literature C.F.Y., C.A.S.; writing—original draft preparation, J.L.Z. and C.F.Y.; writing—review and editing, J.L.Z.; project administration, C.F.Y. All authors have read and agreed to the published version of the manuscript.

Funding: This review was funded by the Korea Program on International Agriculture and Technology (KOPIA), grant "Development of cultivation technologies for corn using biofertilizers in the highlands of Ecuador".

Institutional Review Board Statement: Not applicable.

Informed Consent Statement: Not applicable.

Data Availability Statement: Data sharing not applicable. No new data were created or analyzed in this study. 
Acknowledgments: The authors thank Ricardo Sevilla from Peru and Luis Walquer Arandia from INIAF, Bolivia, for providing information for the elaboration of this review. Additionally, we thank Kang Jin Cho and Alicia Villavicencio (KOPIA-Ecuador) for the support provided to the MBP of INIAP, Santa Catalina.

Conflicts of Interest: The authors declare no conflict of interest.

\section{References}

1. Avila, G. Uso de germoplasma para el mejoramiento de los maíces de altura. In Proceedings of the Memorias de la XXVIII Reunión Latinoamericana de Maíz, Sete Lagoas, Brazil, 22-27 August 1999; pp. 35-41.

2. Yánez, C.; Velásquez, J.; Peñaherrera, D.; Zambrano Mendoza, J.L.; Caicedo, M.; Heredia, J.; Sangoquiza Caiza, C.A.; Quimbita, A. Guía de Producción de Maíz de Altura, Guía No 96 ed.; INIAP, Estación Experimental Santa Catalina: Quito, Ecuador, 2010. Available online: http:/ / repositorio.iniap.gob.ec/handle/41000/2440 (accessed on 16 November 2020).

3. Narro, L. Actividades de colaboración del CIMMYT en Sudamérica. Arch. Académicos USFQ 2017, 9, 27.

4. Jimenez-Esparza, L. La agricultura andina y su problemática. J. Selva Andin. Biosph. 2019, 7, 1-2. [CrossRef]

5. De la Cruz-Díaz, M.; Sevilla-Panizo, R. Adaptación de una variedad heterogénea de maíz a la región alto andina, usando la selección mazorca-Hilera modificada. ACI Av. Cienc. Ing. 2019, 11, 18-29. [CrossRef]

6. Boada, R.; Espinoza, J. Factores que limitan el potencial de rendimiento del maíz de polinización abierta en campos de pequeños productores de la sierra de Ecuador. Rev. Siembra 2016, 3, 67-82. [CrossRef]

7. PREDECAN. Atlas de las Dinámicas del Territorio Andino: Población y Bienes Expuestos a Amenazas Naturales; Comunidad Andina de Naciones: Lima, Peru, 2009; 185p.

8. Villacrés, E.; Yánez, C.; Armijos, L.; Quelal, M.B.; Álvarez, M. El Despertar Gastronómico del Maíz: Recetario; Estación Experimental Santa Catalina: Quito, Ecuador, 2016; 99p.

9. Prasanna, B.M.; Palacios-Rojas, N.; Hossain, F.; Muthusamy, V.; Menkir, A.; Dhliwayo, T.; Ndhlela, T.; Vicente, F.S.; Nair, S.K.; Vivek, B.S.; et al. Molecular breeding for nutritionally enriched maize: Status and prospects. Front. Genet. 2020, 10, 1392. [CrossRef] [PubMed]

10. Palacios-Rojas, N. Calidad nutricional del maíz. Arch. Académicos USFQ 2017, 9, 28.

11. MAG. Cifras Agroproductivas. Sistema de Información Pública Agropecuaria. Available online: http://sipa.agricultura.gob.ec/ index.php/cifras-agroproductivas (accessed on 12 October 2020).

12. Narro, T.; Medina, A.; Vencovsky, R. Selección para incrementar rendimiento y resistencia a pudrición de mazorca en maíz amiláceo. Arch. Académicos USFQ 2017, 9, 65.

13. Rojas-Beltrán, J.; Rojas-Vargas, E.; Bottani-Claros, G. Herramientas moleculares útiles para la conservación, el mejoramiento genético y la producción de maíz en Bolivia. In Proceedings of the Compendio de XXI Reunión Latinoamericana de Maíz, Santa Cruz, Bolivia, 29-31 October 2015; pp. 94-101.

14. Yánez, C.; Zambrano, J.L.; Caicedo, M.; Sánchez, V.H.; Heredia, J. Catálogo de Recursos Genéticos de Maíces de Altura Ecuatorianos; INIAP, Estación Experimental Santa Catalina: Quito, Ecuador, 2003. Available online: https://repositorio.iniap.gob.ec/jspui/ bitstream/41000/43/1/iniapsc201.pdf (accessed on 9 October 2020).

15. Sevilla-Panizo, R. Cincuenta años del programa cooperativo de investigaciones en maíz (PCIM). In Programa Cooperativo de Investigaciones en Maíz (PCIM). Mejoramiento del Maíz en la Sierra del Perú; Promotora Lima: Lima, Peru, 2004; pp. $158-187$.

16. MINAGRI. Plan Nacional de Cultivos del PERU. Campaña Agrícola 2019-2020. Available online: https:/ / cdn.www.gob.pe/ uploads/document/file/471867/Plan_Nacional_de_Cultivos_2019_2020b.pdf (accessed on 16 November 2020).

17. Ortiz, A. Los Maíces en la Seguridad Alimentaria de Bolivia; Centro de Investigación y Promoción del Campesinado (CIPCA): La Paz, Bolivia, 2012; 202p.

18. Timothy, D.H.; Hatheway, W.H.; Grant, U.J.; Torregroza, M.; Sarria, D.; Varela, D. Races of maize in Ecuador, Publication 975 ed.; National Academy of Sciences-National Research Council: Washington, DC, USA, 1963.

19. Grobman, A.; Salhuana, W.; Sevilla, R. Races of Maize in Peru: Their Origins, Evolution and Classification; National Academy of Sciences-National Research Council: Washington, DC, USA, 1961.

20. Ramírez, E.R.; Timothy, D.H.; Díaz, B.E.; Grant, U.J. Races of Maize in Bolivia, Publ. N. 74 ed.; National Academy of SciencesNational Research Council: Washington, DC, USA, 1960.

21. Salhuana, W. Evaluación de los recursos genéticos de maíz. In Cincuenta años del Programa Cooperativo de Investigaciones en Maíz (PCIM); Programa Cooperativo de Investigaciones en Maíz: Lima, Peru, 2004; pp. 252-253.

22. Tapia, C.; Torres, E.; Parra-Quijano, M. Searching for adaptation to abiotic stress: Ecogeographical analysis of highland Ecuadorian maize. Crop Sci. 2015, 55, 262. [CrossRef]

23. Salhuana, W. Logros y perspectivas. In Cincuenta años del Programa Cooperativo de Investigaciones en Maíz (PCIM); Programa Cooperativo de Investigaciones en Maíz: Lima, Peru, 2004; pp. 34-73.

24. Argote, J. Mejoramiento de la calidad proteínica del endospermo del maíz para zonas bajas, intermedias y de valle. In Proceedings of the Compendio de XXI Reunión Latinoamericana de Maíz, Santa Cruz, Bolivia, 29-31 October 2015; pp. 115-119.

25. Arandia, W.; Claure, T. Selección familiar de medios hermanos en la variedad de maíz waltaco para tolerancia a Fusarium sp en el valle alto de Cochabamba. In Proceedings of the Compendio de XXI Reunión Latinoamericana de Maíz, Santa Cruz, Bolivia, 29-31 October 2015; pp. 165-169. 
26. Medina, A. Situación I+D del cultivo de maíz en Perú (Sierra). Arch. Académicos USFQ 2017, 9, 37.

27. Villavicencio, J.P.; Yánez, C.; Zambrano, J.L. Estado de la investigación y desarrollo tecnológico de maíz en el Ecuador. Arch. Académicos USFQ 2017, 9, 36.

28. Claure, T.; Saldaño, D.; Vega, H. Recolección, conservación y utilización del germoplasma nativo y mejorado de maíz en Bolivia. Rev. Inst. Nac. Innovación Agropecu. For. 2016, 8, 21-28.

29. Chahal, G.S.; Gosal, S.S. Principles and Procedures of Plant Breeding; Alpha Science International Ltd.: Harrow, UK, $2002 ;$ p. 604.

30. De Maíz, P. Desarrollo, Mantenimiento y Multiplicación de Semilla de Variedades de Polinización Libre, 2nd ed.; CIMMYT: México, DF, USA, 1999.

31. Sevilla-Panizo, R. Mejoramiento poblacional del maíz amiláceo en la Sierra del Perú, implicancias en la conservación de la biodiversidad y utilización sostenible. In Proceedings of the Compendio de XXI Reunión Latinoamericana de Maíz, Santa Cruz, Bolivia, 29-31 October 2015; pp. 27-36.

32. Caicedo, M. Determinación de la Ganancia Genética Obtenida a Través del Mejoramiento, en las Poblaciones de Maíz (Zea mays L.) Morocho Blanco y Amarillo Duro; [Ingeniero Agrónomo]; ESPOCH: Riobamba, Ecuador, 2001.

33. Zambrano, J.L.; Francis, M.D.; Redinbaugh, M.G. Identification of resistance to Maize rayado fino virus in maize inbred lines. Plant Dis. 2013, 97, 1418-1423. [CrossRef] [PubMed]

34. Caviedes, M. INIAP-180: Nueva Variedad de Maíz de Alto Rendimiento; INIAP: Quito, Ecuador, 1986; 180p.

35. Moreno, F.; Silva, E.; Dobronsky, J.; Heredia, J. INIAP-160: Variedad Mejorada de Maíz "Morocho Blanco" Para la Sierra Ecuatoriana; INIAP, Estación Experimental Santa Catalina: Quito, Ecuador, 1995.

36. Sevilla, R. Sistematización y Edición Temática de la Publicación Sobre la Línea de Base de la Diversidad Genética del Maíz Peruano con Fines de Seguridad; Ministerio de Ambiente: Lima, Peru, 2017; 98p.

37. Chura, J.; Sevilla, R.; García, G.; Beingolea, L.; Blas, R. Híbridos de maíz para la sierra alto andina compatible con un ecosistema de alta diversidad genética. Arch. Académicos USFQ 2017, 9, 71.

38. Danial, D.; Parlevliet, J.; Almekinders, C. Farmers' participation and breeding for durable disease resistance in the Andean Eegion. Euphytica 2006, 153, 385-396. [CrossRef]

39. Medina, A.; Claure, T.; Yánez, C. Mejoramiento genético y participativo para obtener variedades resistentes contra pudrición en Perú, Bolivia y Ecuador. In Memorias de la Conferencia Internacional Sobre: Futuras estrategias Para Implementar Mejoramiento Participativo en los Cultivos de las Zonas Altas en la Región Andina; Danial, D., Ed.; PREDUZA: Quito, Ecuador, $2001 ;$ pp. $172-187$.

40. Yánez, C.; Caicedo, M.; Zambrano, J.L.; Heredia, J.; Mora C., E.; Silva, E.; Vásquez G., J.; Dobronsky, J. Desarrollo de maíces de altura con resistencia duradera a la pudrición de mazorca en Ecuador. In Uso de Marcadores Moleculares en el Mejoramiento Genético de las Plantas; Danial, D., Ed.; INIAP, PREDUZA: Quito, Ecuador, 2007; pp. 118-148. Available online: https://repositorio.iniap. gob.ec/bitstream/41000/5272/1/iniapsc376p118-148.pdf (accessed on 9 October 2020).

41. Eguez, J.; Pintado, P. INIAP-103 "Mishqui Sara", Nueva Variedad de Maíz Blanco Harinoso Para Consumo Humano; Estación Experimental del Austro: Cuenca, Ecuador, 2013. Available online: http:/ / repositorio.iniap.gob.ec/handle/41000/2342. (accessed on 19 January 2021).

42. Gabriel, J. Diagnóstico de las capacidades en mejoramiento genético y biotecnología de cultivos en Bolivia. Rev. Agric. 2010, 47, 10-18.

43. Silva, E.; Dobronskiy, J.; Caviedes, M.; Yanez, C.; Zambrano, J.L.; Heredia, J. INIAP-102 "Blanco Blandito Mejorado", Variedad de Maíz Blanco Harinoso Para la Provincia de Chimborazo; Estación Experimental Santa Catalina: Quito, Ecuador, 2000.

44. Caviedes, M.; Yánez, C.; Silva, E.; Dobronsky, J.; Zambrano Mendoza, J.L.; Caicedo, M.; Heredia, J. Nueva Variedad de Maíz Amarillo Harinoso INIAP-124-Mishca Mejorado; Estación Experimental Santa Catalina: Quito, Ecuador, 2002.

45. Yánez, C.; Zambrano, J.L.; Caicedo, M.; Heredia, J.; Sangoquiza, C.; Villacrés, E.; Racines, M.; Caballero, D. INIAP-199 “Racimo de Uva": Variedad de Maíz Negro; Estación Experimental Santa Catalina: Quito, Ecuador, 2017.

46. INIA. Maíz INIA 603-Choclero, Nueva Variedad Para una Producción Rentable; Estación Experimental Agraria Baños del Inca: Cajamarca, Peru, 2004.

47. INIA. INIA 606-Choclero Prolífico; Estación Experimental Agraria Santa Ana: Huancayo, Peru, 2004.

48. INIA. INIA 607-Chécche Andenes: Variedad Mejorada de Maíz Canchero Para la Sierra sur del Perú; Estación Experimental Agraria Andenes: Cusco, Peru, 2005.

49. INIA. Maíz INIA 615-Negro Canaán: Nueva Variedad de Maíz Morado Para la Sierra Peruana; Estación Experimental Agraria Canaán: Ayacucho, Peru, 2007.

50. INIA. Maíz Amiláceo INIA 618-Blanco Quispicanchi; Estación Experimental Agraria Andenes: Cusco, Peru, 2012.

51. INIA. Maíz Choclero INIA 620_Wari; Estación Experimental Agraria Canaán: Ayacucho, Peru, 2013.

52. INIA. Maíz Canchero INIA 621-Pillpe; Estación Experimental Agraria Canaán: Ayacucho, Peru, 2013.

53. INIA. Maíz Morado INIA 601: Variedad de Maíz Morado Para la Sierra Norte del Perú; Experimental Agraria Baños del Inca: Cajamarca, Peru, 2014.

54. INIA. MINAGRI Desarrolla Nuevo Maíz Amiláceo CUMBEMAINO con Capacidad de Incrementar Producción por Hectárea. Available online: https:/ / www.inia.gob.pe/2020-nota-081/ (accessed on 16 November 2020).

55. CIFP. Pairumani Choclero 2. Available online: https://paisemi.fundacionpatino.org/catalogo/parirumani-choclero-2/ (accessed on 16 November 2020). 
56. INIAF. Registro Nacional de Variedades; INIAF: La Paz, Bolivia, 2009. Available online: https://www.bivica.org/files/variedadesregistro.pdf (accessed on 16 November 2020).

57. CIFP. Pairumani Choclero 3. Available online: https://paisemi.fundacionpatino.org/catalogo/pairumani-choclero---3/ (accessed on 16 November 2020).

58. INIAF. Registro Nacional de Variedades y de Variedades Protegidas; INIAF: La Paz, Bolivia, 2019.

59. Kucharik, C.J.; Ramankutty, N. Trends and variability in U.S. corn yields over the twentieth century. Earth Interact. 2015, 9, 1-29. [CrossRef]

60. Narro, L.; Arcos, A. Maíz híbrido, autofecundación y haploidía en la era pre-genómica. In Proceedings of the Compendio de XXI Reunión Latinoamericana de Maíz, Santa Cruz, Bolivia, 29-31 October 2015; pp. 37-42. 